Copyright $\odot 2008$ SBPJor / Sociedade Brasileira de Pesquisa em Jornalismo
THE END OF

OBJECTIVITY AND

NEUTRALITTY IN CIVIC

AND ENVIRONMENTAL

JOURNALISM

\author{
BEATRIZ DORNELLES \\ PUC-RS, Brazil
}

\begin{abstract}
This article stems from a bibliographic study about American civic journalism and from an exploratory research, using content and documental analysis of data collected by interview, questionnaire and copies of neighborhood and small town newspapers that have community characteristics, resulting in an comparative analysis of the two types of journalistic practice during the 1990s and the first five years of the 21 st century. This kind of journalism, marked by the participation of the community, was also called communitary journalism, engaged journalism, popular journalism and public journalism. All of them have in common the centralizing of the profession's practical objectives on encouraging efforts to advance citizenship, improving public debate, reviewing public life and contributing to the improvement of democracy. Based on this study, a proposal arose regarding some themes that are present in the daily press, especially the environment theme, calling for the end of the practical journalism that advocates a "sham neutrality, impartiality and objectivity".
\end{abstract}

Key-Words: Civic Journalism, Neutrality, Impartiality

\title{
INTRODUTION
}

In Brazil, there are a great number of researchers that advocate the adoption of a new style of journalism, especially to keep track of environmental issues within society. First, because it is necessary to think beyond just keeping people informed about events - especially regarding mankind's actions with respect to the environment and their effects - but also because we have to educate people so that, living in a democracy, it becomes possible to organize and mobilize the public to demand changes that bear in mind the future of our children, grandchildren and all subsequent generations.

The Brazilian state of Rio Grande do Sul has a tradition in ecological 
awareness that began in the first years of the 1970s, when a student in the Federal University prevented the government - at that time, a military dictatorship - from toppling a tree in one of the main avenues of the state capital, Porto Alegre. Since then, with the help of some outstanding international ecologists, such as José Lutzemberg, the people of our state have revealed a special sensitivity concerning the protection of nature.

I would like to emphasize, for example, that many of the social movements in Porto Alegre are devoted to environmental causes. It is the subject that receives the greatest coverage in the 31 neighborhood newspapers that are circulating in the city. Also important internationally acclaimed stories have denounced issues related to the environment.

Therefore, our proposal regarding environmental journalism, combined with other very similar proposals by journalists and researchers from São Paulo and Rio de Janeiro, has the intention of ending the sham neutrality and impartiality of the press. The issue is not restricted to a merely technical question; it is not about just following (and reproducing) the principles established by journalism manuals, based on dubious concepts of objectivity, neutrality, impartiality, etcetera. Those rules do not apply anymore, as Wilson da Costa Bueno also declared in his theoretical and practical proposal for environmental journalism.

\section{Environmental journalism}

According to Bueno (2007), the environmental theme arises as a result of civic militancy, not political party militancy. It is always complex because it is not limited to a merely technical or scientific level, but combines an economic perspective, a political will, a socio-cultural component, and so on. "The mistake resides in not realizing the intricate connections between environment, economy, culture, politics and society; in reducing, by naivety or lack of knowledge, the newspaper guideline to a specific instance, simplistic, in a reductionism that benefits only the corporations' interests", analyzes Bueno (p.38).

When journalism is organized in sections, it inhibits the adoption of a multidisciplinary perspective, essential for the production of environmental reporting. To view the environment only from a technical or mostly economic perspective means impoverishing the journalistic coverage. Journalists should call upon non-specialized sources for the debate.

What we mean is that the environmental issue basically needs to play an educational role, systematizing concepts and experiences, enabling the participation of ordinary people in the debate. These sources can be the representatives of the forest dwellers, farmers, artisanal fishermen, 
"erva mate" producers, industry workers, workers in general, members of indigenous groups and the environmental Non-Governmental Organizations.

To engage in that kind of reporting, one must remember that many journalism models have been tested in many countries, in accordance with the latters' cultural peculiarities. Nevertheless, it is possible to observe that in the last 30 years there has been a tendency to practice what was called "participative journalism", also known by different names such as communitary journalism, engaged journalism, popular journalism, public journalism, civic journalism. What they all have in common is the fact that they centralize the objectives of professional practice in efforts to stimulate citizenship, improving public debate, reviewing public life and contributing to the improvement of democracy.

Perceiving the feeling of frustration of many people with superficial journalism coverage, based on spectacle, on the opportunity for good pictures, on controversies involving secondary issues, on the dependence on official sources, on the excess of crime stories, and in the absence of debates about public policy and issues considered essential for the readers - such as environmental issues - some journalists decided to change the status quo, sharing with the people an activist role in an attempt to improve the quality of life in the community and abandoning the traditional neutral, impartial and objective role.

Nowadays, no one wants to be neutral, a mere observer and only sometimes critical. People want to have a greater role; want to contribute to the growth of citizen participation in issues involving public policies. One of the best examples that we can cite regarding this journalism is Civic Journalism (already tried in the U.S.A.).

After applying several strategies for political campaign coverage based on citizen agenda, in 1994 the Charlotte Observer, a North Carolina newspaper, released a Civic Journalism Project in a city with high levels of criminal activity. The newspaper printed a series of stories about the neighborhoods with the highest levels of violence, did surveys, hired professionals to coordinate community relationships and organized meetings with the residents. Among other project results, there was a significant drop in the number of violent crimes.

With the support of institutions from different sectors (public, private and social), more than 200 civic journalism projects were put into practice in the United States, seeking to renew American journalism and contributing to making citizen participation in public life more dynamic. For this purpose, many techniques for surveying public opinion were 
used with the objective of identifying the "citizen agenda". In several cases, the journalists became active partners in the search for the solution of community problems.

Before going deeper into this new journalism style that is necessary in the Brazilian population centers, I want to comment that in the state of Rio Grande do Sul, according to research conducted by $\mathrm{me}^{1}$ utilizing reception studies, there are already several newspapers in small cities around the countryside practicing a similar type of civic journalism, as well as in the state capital, Porto Alegre, where there are neighborhood newspapers with communitarian focus.

A similar treatment has been provided by journalist and researcher Wilson da Costa Bueno in dealing with the environmental coverage issue in lectures and books, which we believe can also be relevant to other sectors. According to Bueno,

Environmental journalism needs to have a revolutionary character committed to a paradigm change, has to see beyond appearances and not be complacent with those who dominate environmental issues to create or strengthen their image. It should always suspect pretentious governmental and organizational environmentalist discourse, seeking coverage apart from isolated actions, almost always used as marketing resources (BUENO, 2007: 17).

We believe that Bueno's proposal can be applied to all journalistic coverage, especially to the creation of main stories for the political, economic and social issues sections, transforming this redirection of journalism making. That means, as Bueno declared, "repudiating neutrality, taking sides, investigating the causes and consequences of economic groups' harmful action that degrade the planet. It is, above all, supporting with courage the urgent need for improving the citizens' quality of life." (Ibid., p.21).

\section{Press and People Interests}

We agree, however, that we are not proposing any practical novelty, since the current coverage is already partial, as it protects, supports and disseminates business interests, supported by agencies and public relations firms. What we want is the press to start advocating explicitly the interests of all the people in the society, not just those of the elite.

As Bueno notes, agrochemical industries frequently issue releases with "the cynical publicity of their linkage with sustainable agriculture" (2007:18). Stories about mining and the importance of the eucalyptus "forest" are examples of this. 
Most of the time, those stories are based on so-called technical knowledge and have as their main objective the spreading of the capitalist logical arguments that seek to relate increased profits and productivity with development. They unpretentiously continue supporting standardization and homogenization, sparing no efforts to convince everybody of diversity's disadvantages, of local solutions' inefficiency, of the traditional communities' store of knowledge, at the same time that they take it over and patent it (BUENO, 2007: 18).

In the opinion of Vandana Shiva ${ }^{2}$ (Ibid.), the new modernization ideology is a travesty of scientific knowledge that disseminates throughout the world and promotes mono-cultural minds, i.e., the hegemony of a perspective that contemplates natural resources as commodities and classifies as pests everything that cannot be quickly converted into money.

In practice, Bueno interprets, the press has been adopting a sustainable development concept which conforms to business interests and reflects a merely reformist ideology, that is more concerned with the GDP and increased exports than with the population's access to food, education, drinking water, sanitation and health services. That is to say, the journalistic stories printed by the press, supposedly a model of impartiality, neutrality and objectivity, show an entrepreneurial view that includes its own survival and treat the environment as something which, if not managed correctly, can harm good business management.

This vision, that tends to be hegemonic even among professionals who work in the environmental press, reduces environment and its preservation to a merely economic issue, disconnected from sociocultural and political values and principles. For the press, the land reform movement, the food safety issue, genetic pollution, the dams' social impact, the financial whirl and even the priorities in terms of science and technology investments are distant themes and not included in the concept. The concept of sustainable development is contaminated, therefore, by the financial-economic perspective and it is seen especially as a business management problem. There are entrepreneurs that believe that the sustainability that interests them is that which guaranties their own business survival (BUENO, 2007: 20).

We understand, as Bueno does, that the construction of sustainable life has to include a commitment to ethics, professionalism and the unrestricted support for all those who are hungry, thirsty, homeless, uneducated, unemployed and without health support, who are subjected to an undignified life. 
The construction of sustainable life requires the immediate and permanent commitment to 'indignation pedagogy' as referred to by Paulo Freire. The authentic (environmental) 3 journalist must have the capacity and willingness to be outraged by injustice and promote conditions for attenuating it to a minimum (Idem, p. 22).

On the subject of Paulo Freire, there is still a new journalism, based on the Education/Communication interface, that in recent years has been promoted to such a point that the research works, theoretical papers, practical proposals that involve new lines of research in universities, training courses and specialized publications have multiplied.

We already have a great number of actions and reflections directed to non-formal and informal education; the critical vision of the media; the experience of producing printed journalistic material by higher level and basic schools; the new computer technologies that create new challenges for pedagogic study; the training of "educomunicadores" ("educational communicators") - Mário Kaplum's term that summarizes in the same word "the need to give birth to a new kind of professional that can think in an articulated way in two areas very interdependent in contemporary society" (CITTELI, 1999: 136-7).

It is important to remember that Reception and Mediation Studies, resulting from popular culture interests, leave behind the concept of journalism as a mere informative text and prioritize the construction of meaning by interpretative communities. They focus on news-related products as meaning and knowledge constructing agents and sources. It can be said that in this relation between vehicle/channel and reader/ interpreter, the relations that are established create a mutual identity and improve the sense and meaning of the messages.

It is very important also to quote sociologist Castells, for whom a new economy was born in the last two decades, informative and global at the same time. Informative because society's macro-organisms (companies and nations) depend on its capacities to generate, process and distribute information; global because all productive activities that involve goods' consumption and circulation are organized in flows, in connectivity. Castells (1999) believes that we are living at a historical moment which points to the construction of a human organization based on information and knowledge-forming technologies.

Current discussion involves the redefinitions of relationships between men, women and children, of sexuality and personality; the environmental awareness intrinsic to institutions with political/State 
support; political systems plunged into a crisis of legitimacy; fragmented and local social movements; differences in primary, religious, ethnic, territorial and national identities.

The social function of today's media has to be understood in the context created by the global network of communication systems. We are facing a new level of reality comprehension, in which we encounter several cultural identities and actors in a globalized economic scene, permeated by multidimensional politics. In that sense, it is evident that the media have gone beyond their function historically considered as "technical", and the work based on information is also surpassing statistical data (VERAS JÚNIOR, 2005).

Though the themes related to science are always seen as "reserved" for an intellectual elite, scientific publications have grown in a significant way. This is explained by many factors, such as a greater presence of scientific and highly technological products in daily life; the computerization of many social activities; the technical evolution of medicine and drugs, aesthetics, cosmetics and the household appliances industry; global warming and many other natural phenomena, all of which have been propelling the need to popularize scientific information.

In Porto Alegre, for example, an analysis of the issues covered by 32 neighborhood newspapers has shown that the environment was among their three most frequent issues. Unfortunately, the stories presented the same characteristics as those of the major newspapers and did not deepen the discussion. However, the environment issue had permanent coverage, being present in practically all editions in all the neighborhood newspapers.

Going back to the reflection on a new proposal for environmental journalistic coverage, we propose the following changes, along the lines of American Civic Journalism (TRAQUINA, 2003: 13): we need to go beyond the mission of reporting to a greater mission of helping to improve public life; to ignore the notion of "indifferent observer" and assume the role of "righteous participant", to perceive the public as an actor in democratic life and not just as a consumer; to make it a priority for journalism to establish a connection with the citizenry.

Therefore, for this new kind of journalism, it becomes necessary for journalists to stimulate the citizens' involvement in public life transforming media professionals into righteous participants, with the use of a new set of work tools. That is, a more participative journalism in the construction of a more vibrant public space and in the resolution of communitarian issues. 
There is practically a consensus, at least in the academic field, that journalism can and must have an important role in reinforcing citizenship, improving public debate and bringing public life back to the agenda. It is understood that there must be a willingness to destroy old routines, a desire to again be connected with citizens and their concerns, an emphasis on serious debating as a main activity in a democracy and a focus on citizens as actors in the public drama instead of spectators (ROSEN apud TRAQUINA, 2003: 15).

\section{Objectivity}

As for the concept of objectivity, the American researchers connected with this movement understand that its intellectual relevance as epistemology is obsolete and that today it corresponds to a desire for justice. According to them, another interpretation of the concept of objectivity is crucial to journalistic credibility and represents a noble and necessary ideal in democracy.

It is understood that in future years it will be crucial for people in journalism to declare the end of neutrality with respect to certain issues. According to Rosen (Ibidem), "journalists may face hardships on the path to their own philosophy, one that can replace objectivity with something stronger and, if I may say so, more exciting" (1993:53).

In Brazil, Wilson da Costa Bueno, with his conceptual and practical proposal for environmental journalism, also deals with the issue of objectivity and neutrality, saying:

Right now, no more neutrality, and objectivity must be seen with restrictions because in practice all newspaper reporting, all discourse requires a story, a reading and a commitment (2007:37).

Turning from Bueno's proposal for environmental journalism to journalism in general, with respect to newspaper reports we should have the following: a newspaper report represents a commitment fulfilled from a particular point of view of the world and should be planned and executed with this function in mind. If the news guideline, the sources, the interview focus are not based on a multi- and interdisciplinary view, politically engaged, deeply committed, we will have a story that distorts the majority interest, stripped of political and economical power.

The journalistic guideline must be committed to an ideal that something has to be done, there are problems and challenges to be faced, there are interests at stake and journalism and journalists must 
play a fundamental role in making all this explicit. Events in general cannot be seen from a merely technical or scientific angle, since they are linked to economical issues, political will and socio-cultural components, among other aspects.

The many interests at stake are considered, and the proposals made for a new kind of journalism reaffirm the social responsibility area in a mercantile society, where even in the newspaper offices money has more influence than editorial decisions. Some enthusiastic researchers demand a complete rupture with the current overriding values and create a caricature of the traditional press, attacking it as corrupt; and answer critics by calling them reactionaries

We point out that this new kind of journalism proposes to exchange the fragmentary nature of traditional professional practices for a new attitude based on greater attention given to each issue. "Instead of jumping from event to event, it would be desirable to deeper the relevant stories so as to focus community attention on them. Only then the citizens could deliberate with knowledge about the main issues of community life" (MÁRIO MESQUITA, 2003:23).

According to Mesquita, in the origin of the theory regarding Civic Journalism, there were essentially three kinds of factors: the "communitarian" theories' influence, in the field of political philosophy; the criticism of journalists' behavior with regard to politics and politicians, understood as an systematically skeptical attitude, capable of contributing to the citizens' lack of interest in public life; and the press credibility crisis and, in general, the media crisis, detected by public opinion studies, executed in a systematic way and subsidized by American media companies.

The new journalist profile emphasizes a willingness to see democracy as something that we have to create, reinvent, re-imagine. In this sense, we cannot and should not be neutral in issues related to people's participation in public life, to the existence of a wide, serious public debate, to the functioning of a political system and other issues related to political democracy. The journalism professional cannot be indifferent to the quality of democratic practices.

In summary, these are some issues that must guide the coverage of environmental issues. Personally, I cannot believe that in Brazil the large communication companies, owners of the main and most powerful mass media, would promote a reform in journalistic procedures. But I believe that a parallel press, as an alternative to the mass media, among other changes, can force important changes in Brazilian journalism practices. 
Finally, I quote Paulo Freire's reflection, in Extension or Communication? (1968:52): "Education is communication and dialog, in that it is not just a transfer of knowledge, but a meeting of interlocutory subjects that seek the significance of meanings".

\section{| NOTAS}

1 I have been conducting scientific research, with CNPq and Fapergs support, on small town and neighborhood press since 1995.

2 See Monoculturas da mente: perspectivas da biodiversidade e da biotecnologia. São Paulo, Gaia, 2003.

3 The parentheses are mine, because Bueno presents his proposal exclusively for environmental journalists; I advocate the same posture for all areas of journalistic coverage.

\section{BIBLIOGRAPHY}

Bueno, Wilson da Costa. Comunicação, Jornalismo e Meio Ambiente: teoria e pesquisa. São Paulo: Mojoara, 2007.

Castell, Manuel. A sociedade em rede. Rio de Janeiro: Paz e Terra, 1999.

Citelli, Adilson. Comunicação e Educação. São Paulo: Senac, 1999.

Freire, Paulo. Extensão ou Comunicação? São Paulo: Paz e Terra, $12^{\mathrm{a}}$ edição, 2002.

Mesquita, Mário. As tendências comunitaristas no Jornalismo Cívico. Comunicação apresentada no colóquio "Os desafios da Imprensa Regional", promovido pelo Fórum Açoriano, na Câmara Municipal de Ponta Delgada, Portugal, 2000. 
Shiva, Vandana. Monoculturas da mente: perspectivas da biodiversidade e da biotecnologia. São Paulo, Gaia, 2003.

Traquina, Nelson e Mesquita, Mário. Jornalismo Cívico. Lisbon: Livros Horizonte, 2003.

Veras Júnior, José Soares de. Da informação ao conhecimento. Site: www. bocc.ubi.pt. Accessed on 10/10/2007.

Beatriz Dornelles has a doctorate in Communication from the University of São Paulo (USP). She is a journalist and has been a teacher (at PUC/RS) since 1993. E-mail: biacpd@pucrs.br. 